\title{
The phenotypic and molecular genetic spectrum of Alström syndrome in 44 Turkish kindreds and a literature review of Alström syndrome in Turkey
}

\author{
Ayşegül Ozantürk, Jan D Marshall, Gayle B Collin, Selma Düzenli, Robert P Marshall, Şükrü Candan, \\ Tülay Tos, İhsan Esen, Mustafa Taşkesen, Atilla Çayır, Şükrü Öztürk, İhsan Üstün, Esra Ataman, Emin Karaca, \\ Taha Reşid Özdemir, İlknur Erol, Fehime Kara Eroğlu, Deniz Torun, Erhan Parıltay, Elif Yılmaz-Güleç, \\ Ender Karaca, M Emre Atabek, Nursel Elçioğlu, İlhan Satman, Claes Möller, Jean Muller, Jürgen K Naggert \\ and Rıza Köksal Özgül
}

Journal of Human Genetics (2015) 60, 51; doi:10.1038/jhg.2014.101

Correction to: Journal of Human Genetics (2015) 60, 1-9; doi:10.1038/ jhg.2014.85; published online 9 October 2014

Since the advance online publication of this article, the authors of the above paper have noticed errors in the list of authors and affiliations.
Article with correct authors information now appears in this issue. The online html and pdf versions have also been rectified. The authors apologize for any inconvenience caused. 